
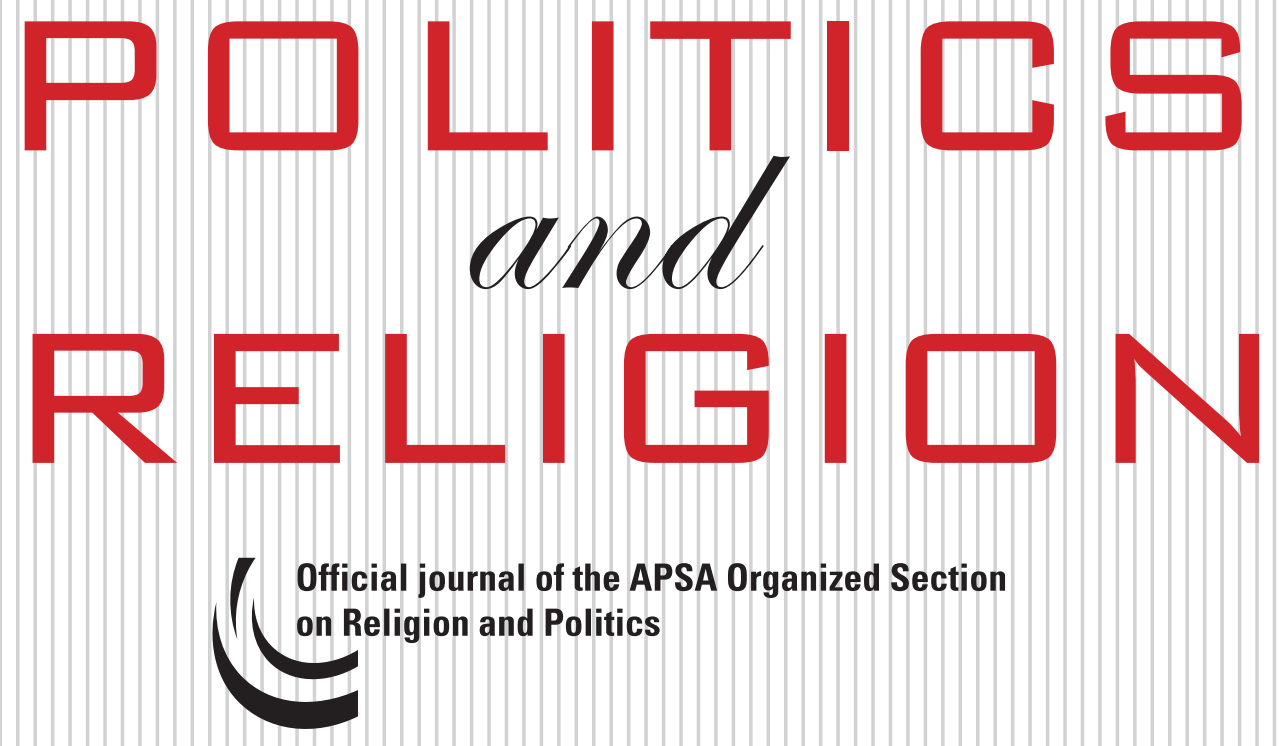

V 


\title{
POLITICS AND RELIGION
}

\author{
EDITOR-IN-CHIEF
}

Elizabeth Oldmixon

University of North Texas

Elizabeth.Oldmixon@unt.edu

\section{EDITORS}

Mehmet Gurses

Florida Atlantic University

gurses@fau.edu

\author{
Nicholas Tampio \\ Fordham University \\ tampio@fordham.edu
}

\section{BOOK REVIEW EDITOR}

Ann Marie Wainscott

Department of Political Science

Miami University

349 E. High Street

218 Harrison Hall

Oxford, OH 45056

annmariewainscott@gmail.com

\section{EDITORIAL BOARD}

Bethany Albertson, University of Texas at Austin, USA

Victor Asal, University at Albany, SUNY, USA

Tongdong Bai, Fudan University, Shanghai, China

Ceren Belge, Concordia University, USA

David Bosworth, Catholic University of America, USA

R. Khari Brown, Wayne State University, USA

David Campbell, University of Notre Dame, USA

Michael Correa-Jones, University of Pennsylvania, USA

Daniel Dreisbach, American University, USA

Michael D. Driessen, John Cabot University, Italy

Amanda Friesen, Indiana University-Purdue University, Indianapolis, USA

Farah Godrej, University of California-Riverside, USA

Cengiz Gunes, The Open University, UK

James Guth, Furman University, USA

Ekrem Karakoc, Binghamton University, SUNY, USA
Katherine Knutson, Gustavus Adolphus College, USA

Karrie J. Koesel, University of Notre Dame

Geoffrey C. Layman, University of Notre Dame, USA

Andrew F. March, University of Massachusetts Amherst, USA

Michele Margolis, University of Pennsylvania, USA

Mike Medeiros, University of Amsterdam, Denmark

Kassra A.R. Oskooii, University of Delaware, USA

Ani Sarkissian, Michigan State University, USA

Marwa Shalaby, University of Gothenburg, Sweden

Amy Erica Smith, Iowa State University, USA

Anand Edward Sokhey, University of Colorado, Boulder, USA

Lavinia Stan, St. Francis Xavier University, Canada Isak Svensson, Uppsala University, Sweden

Sultan Tepe, University of Illinois at Chicago, USA Lars Tønder, University of Copenhagen, Denmark

Politics and Religion, is an international journal publishing high quality peer-reviewed research on the multifaceted relationship between religion and politics around the world. The scope of published work is intentionally broad and we invite innovative work from all methodological approaches in the major subfields of political science, including international relations, American politics, comparative politics, and political theory, that seeks to improve our understanding of religion's role in some aspect of world politics. The Editors invite normative and empirical investigations of the public representation of religion, the religious and political institutions that shape religious presence in the public square, and the role of religion in shaping citizenship, broadly considered, as well as pieces that attempt to 


\section{Politics and Religion}

\section{Volume 12, Number 1, March 2019}

\section{ARTICLES}

Catholicity Without Leviathan: Stanley Hauerwas's Perspective on the Church as an Alternative Political Community

Ionut Untea

Islam and the Islamic State's Magazine, Dabiq

Tim Jacoby

Israel and the Islamist Challenge: Old Dilemmas, New Approaches Suheir Abu Oksa Daoud

Measurement and Conceptual Approaches to Religious Violence:

The Use of Natural Language Processing to Generate Religious

Violence Event-Data

Robert Brathwaite and Baekkwan Park

Political Mobilization in American Congregations: A Religious

Economies Perspective

Paul A. Djupe and Jacob R. Neiheisel

Sexuality, Political Polarization, and Survey Reports of Religious

Nonaffiliation

Philip S. Brenner

What Business do Businesses Have with the Free Exercise of Religion?

Judith Lynn Failer

\section{REVIEW ESSAY}

American Covenant: A History of Civil Religion from the Puritans to the Present. By Philip Gorski

The Politics of the Sacred in America: The Role of Civil Religion in Political Practice. By Anthony Squiers

Andrew R. Murphy 


\section{BOOK REVIEWS}

Religious Activism in the Global Economy: Promoting, Reforming, or Resisting Neoliberal Globalization?. Edited by Sabine Dreher and Peter J. Smith

Reviewed by Daniel Béland

Deadly Clerics: Blocked Ambition and the Paths to Jihad.

By Richard A. Nielsen

Reviewed by Paul A. Djupe

The Contemporary Islamic Governed State: A Reconceptualization. By Joseph J. Kaminski

Reviewed By Saeed A. Khan 208

CONTRIBUTORS TO THIS ISSUE 211 


\section{Politics and Religion INSTRUCTIONS FOR CONTRIBUTORS}

Manuscripts must be submitted at www.editorialmanager.com/prj. The Editors may be contacted at PandRJournal@unt.edu.

\section{Scope}

Politics and Religion is an international journal publishing high quality peerreviewed research on the multifaceted relationship between religion and politics around the world. The scope of published work is intentionally broad and we invite innovative work from all methodological approaches in the major subfields of political science, including international relations, American politics, comparative politics, and political theory, that seeks to improve our understanding of religion's role in some aspect of world politics. The Editors invite normative and empirical investigations of the public representation of religion, the religious and political institutions that shape religious presence in the public square, political theological debates, and the role of religion in shaping citizenship, broadly considered, as well as pieces that attempt to advance our methodological tools for examining religious influence in political life.

\section{Format}

The Journal considers two kinds of manuscript submissions:

Articles. Articles provide original research addressing any of the topics suggested in the journal's Scope. They should be about 9,000 words in length, including notes and references, but not tables and figures. Appendices may be placed on a website for publication in order to conform to word count limits, but must be included for review.

Notes. These are problem-driven research manuscripts that address timely political issues, replicate existing research, and/or report null findings. Notes should be about 4,500 words in length, including notes and references, but not tables and figures. Appendices may be placed on a website for publication in order to conform to word count limits, but must be included for review.

\section{Manuscript Preparation}

1. Manuscripts (including notes and references) must be double-spaced, with oneinch margins and 12-point font (preferably Times New Roman or Garamond). The Journal accepts files in Microsoft Word. 
2. The Editors encourage authors to write in a concise manner, avoiding unnecessary jargon and overly complex sentence constructions. The goal in academic writing is effective and efficient communication. In that spirit, parsimony is a virtue. Authors should use gender-neutral language where appropriate.

3. The author must submit a title page file with his or her full contact information (including email address, telephone number and institutional affiliation), an abstract of about 150 words, and a statement acknowledging outside funding and indicating where replication data will be made available (should the author choose to make it available). Separately, the author must submit the manuscript file with all identifying information removed. The manuscript file should begin with the text of the paper, not with a title and abstract.

4. Authors should indicate where tables or figures should be placed in the text; tables and figures should be referenced in the first paragraph following placement indication. They should be numbered consecutively and included on separate pages appearing after the reference section. Figures should be ready for photographic reproduction. Charts, graphs, or other artwork should be professionally rendered or computer generated. Photographs should be clearly printed and should remain legible after a $50 \%$ reduction.

5. References and notes should conform to the APSA Style Manual. Authors should include full volume, issue, and page numbers for article references and page numbers for book chapters. Authors' acknowledgments or other personal notes will appear as an unnumbered note at the foot of the first page.

6. Self-citations should be omitted where their inclusion would likely signal the author's identity, such as the citation of a conference paper or dissertation. Authors may include the following parenthetical notation in the text in place of the normal citation: (self-citation omitted).

7. Endnotes for content (not references) should be used rather than footnotes and employed sparingly. Notes should be numbered consecutively throughout the manuscript.

8. Where possible, authors must provide full citations for datasets.

\section{Ethics, Transparency, and Conflicts}

The Editors will not submit articles or notes, either as authors or co-authors, to Politics and Religion during their term of service. A member of the Editorial Board will manage submissions from students and faculty at the Editors' home 
departments. Members of the Editorial Board and the Book Review Editor may submit articles or notes for peer review during their terms of service.

The Editors take academic integrity very seriously. Accepted manuscripts will be checked for plagiarism. Depending on the gravity of the irregularity, submissions containing redundancies, copyrighted material, or lacking sufficient citation to outside scholarship or data may be returned to the author for clarification or rejected. Additional actions are possible.

The Editors affirm the importance of data transparency in evidence-based political science research. Authors are required to clearly specify their analytical techniques and outside sources of funding and encouraged to make their data publically available at the time of publication. The Editors understand, however, that the latter may not be possible or ethical, to the degree that data are proprietary, sensitive, or newly collected. Authors using publically available data should provide a DOI citation where possible.

\section{Use of Color}

Charges apply for all color figures that appear in the print version of the journal. At the time of submission, contributors should clearly state whether their figures should appear in color in the online version only, or whether they should appear in color online and in the print version. There is no charge for including color figures in the online version of the Journal but it must be clear that color is needed to enhance the meaning of the figure, rather than simply being for aesthetic purposes. If you request color figures in the printed version, you will be contacted by CCC-Rightslink who are acting on our behalf to collect Author Charges. Please follow their instructions in order to avoid any delay in the publication of your article.

\section{Originality and Copyright}

Papers with multiple authors are reviewed with the assumption that all authors concur with its submission. A Copyright Transfer Agreement, with certain specified rights reserved by the author, must be signed and returned to the Editor by senior authors of accepted manuscripts, prior to publication. Politics and Religion does not accept manuscripts for review that are under review elsewhere, previously published, or already committed for publication.

Last updated 1st January 2017 